Institute of $\mathbf{F}_{\text {ood and }} \mathbf{A}_{\text {gricultural }} \mathbf{S}_{\text {ciences }}$

\title{
2003 Handbook of Employment Regulations Affecting Florida Farm Employers and Workers: Transportation -- Motor Carrier Safety Regulations for Transporting Migrant Farm Workers [Federal] ${ }^{1}$
}

Leo C. Polopolus, Michael T. Olexa, Fritz Roka, and Carol Fountain ${ }^{2}$

\section{Purpose}

Establishes safety and other standards regarding the transportation of migrant farmworkers.

\section{Applicable Laws}

The transportation of migrant and seasonal farmworkers is governed by the DOT's Federal Motor Carrier Safety Regulations and regulations adopted by the U.S. Department of Labor (DOL) in implementing the Migrant and Seasonal Agricultural Worker Protection Act (MSPA).
The DOL adopted, virtually intact, the Federal Motor Carrier Safety Regulation dealing with the transportation of migrant and seasonal agricultural workers.

In addition, the DOL adopted its own vehicle standards for automobiles and station wagons used to transport migrant and seasonal agricultural workers and all other vehicles used to transport migrant and seasonal agricultural workers for trips of seventy-five miles or less (excluding day-haul operations). (See EDIS document FE406, Migrant and Seasonal Agricultural Worker Protection Act (MSPA) [Federal $].)$

1. This is EDIS document FE418, a publication of the Department of Food and Resource Economics, Florida Cooperative Extension Service, Institute of Food and Agricultural Sciences, University of Florida, Gainesville, FL. Published July 2003. This information is included in Circular 1200, Handbook of Employment Regulations Affecting Florida Farm Employers and Workers. First published February 1992 as Circular 1043 . Revised December 2002 as Circular 1200. Please visit the EDIS website at http://edis.ifas.ufl.edu.

2. Leo C. Polopolus, Professor Emeritus, Department of Food and Resource Economics, University of Florida, Gainesville, FL; Michael T. Olexa, Professor, Department of Food and Resource Economics, University of Florida, Gainesville, FL; Fritz Roka, Associate Professor, Department of Food and Resource Economics, Southwest Florida Research and Education Center, Immokalee, FL; and Carol Fountain, Assistant Editor, Department of Food and Resource Economics, University of Florida, Gainesville, FL; Florida Cooperative Extension Service, Institute of Food and Agricultural Sciences, University of Florida, Gainesville, FL.

This document is designed to provide accurate, current, and authoritative information on the subject. However, since the laws, administrative rulings, and court decisions on which it is based are subject to constant revision, portions of this publication could become outdated at any time. This publication is distributed with the understanding that the authors are not engaged in rendering legal or other professional advice, and the information contained herein should not be regarded as a substitute for professional advice. For these reasons, the utilization of these materials by any person constitutes an agreement to hold harmless the authors, the Institute of Food and Agricultural Sciences, and the University of Florida for any liability claims, damages, or expenses that may be incurred by any person as a result of reference to or reliance on the information contained in this publication.

The Institute of Food and Agricultural Sciences is an equal opportunity/affirmative action employer authorized to provide research, educational information and other services only to individuals and institutions that function without regard to race, color, sex, age, handicap, or national origin. For information on obtaining other extension publications, contact your county Cooperative Extension Service office. Florida Cooperative Extension Service/Institute of Food and Agricultural Sciences/University of Florida/Christine Taylor Waddill, Dean. 
The regulations contain provisions setting forth the qualifications of drivers or operators; the driving of motor vehicles, parts, accessories necessary for safe operation, hours of service by drivers, maximum driving time, and inspection and maintenance of motor vehicles.

\section{Operator Qualifications}

Regulations on the qualifications of drivers provide that no person shall drive any motor vehicle carrying migrant farmworkers unless he or she meets the following minimum qualifications:

- Be twenty-one years of age or older.

- Have no mental, nervous, organic, or functional diseases likely to interfere with safe driving.

- Have no loss of foot, leg, hand, or arm.

- Have no loss of fingers or impairment of foot, leg, hand, or arm that prevents safe driving.

- Have visual acuity of at least 20/40 corrected.

- Have hearing of not less than $10 / 20$ in one ear.

- Not be addicted to narcotics or habit-forming drugs or excess use of alcoholic beverages.

- Have a physical examination by a licensed doctor of medicine or osteopathy at least every thirty-six months and carry a certificate of physical examination at all times.

- Read and speak English.

- Possess a valid driving permit applicable to the vehicle being driven (i.e., a Commercial Driver's License with a passenger transport endorsement).

\section{Operator Regulations}

Regulations governing the driving of motor vehicles carrying migrant farmworkers include:

- Driving rules to be obeyed.

- Driving while ill or fatigued.
- Alcohol beverages.

- Schedules to conform to speed limits.

- Equipment and emergency devices.

- Safe loading:

- Distribution and securing of load.

- Doors, tarpaulins, tailgates, and other equipment.

- Interference with driver.

- Property on motor vehicle.

- Maximum passengers on motor vehicles.

- Rest and meal stops.

- Kinds of motor vehicles in which workers may be transported.

- Lighting devices and reflectors.

- Limitation on distance of travel.

- Ignition of fuel precautions.

- Carrying reserve fuel.

- Driving by unauthorized persons.

- Protection of pasengers from weather.

- Unattended vehicle precautions.

- Railroad grade crossings.

\section{Vehicle Specifications}

The regulations also specify certain parts and accessory requirements for vehicles used to transport migrant farmworkers as follows:

- Lighting devices.

- Brakes.

- Coupling devices (fifth wheel mounting and locking).

- Tires. 
- Passenger compartment:

- Floors.

- Sides.

- Nails, screws, and splinters.

- Seats.

- Protection from weather.

- Exit.

- Gate and doors.

- Ladders and steps.

- Handholds.

- Emergency exits.

- Communication with driver.

- Protection from cold. Prohibited heaters include:

- Exhaust heaters.

- Open flame heaters.

- Heaters permitting fuel leakage.

- Heaters permitting air contamination.

- Heaters not securely fastened.

\section{Penalties}

Violations of the federal Motor Carrier Safety Regulations carry fines ranging from $\$ 1,000$ for the first offense up to $\$ 10,000$ for willful repeat offenses.

\section{Inspections and Licensing}

For vehicle inspections relative to farm labor contractor certification, contact the local U.S. Department of Labor, Wage and Hour Division office. For licensing, contact the Florida Department of Highway Safety and Motor Vehicles.

For local offices, see the telephone directory for
- U.S. Government

- Labor, Department of

- Wage and Hour Division

(See EDIS document FE419, Transportation of Migrant Farm Workers [State].)

\section{Related Information}

- Federal Motor Carrier Safety Regulations, C.F.R. Title 49, Chapter III, Subchapter B, Part 398 U.S. Department of Transportation, Federal Highway Administration, Bureau of Motor Carrier Safety.

- Commercial Driver's License: Manual for Truck and Bus Drivers, Florida Department of Highway Safety and Motor Vehicles.

\section{Responsible Agency}

U.S. Department of Transportation

Federal Highway Administration

Office of Motor Carrier Safety

61 Forsyth Street SW, Suite 17T75

Atlanta, GA 30367

(404) 562-3600

http://www.fmcsa.dot.gov/aboutus/aboutus.htm 